\title{
ÉTICA AMBIENTAL E SUSTENTABILIDADE: O CAMINHO MULTIDIMENSIONAL
}

\section{LUIZ HENRIQUE CRUZ}

Mestrando em Direito Empresarial e Cidadania do Centro Universitário CuritibaUNICURITIBA; Mediador Judicial pelo Tribunal de Justiça do Rio de Janeiro; Estudante de Pós-Graduação em Registros Públicos pela Universidade Cândido Mendes- UCAM - RJ. E-mail: lhenrique.s.adv@gmail.com.

\section{ELOIZA SACRAMENTO}

Mestranda em Direito Empresarial e Cidadania no UNICURITIBA - Centro Universitário Curitiba, Bacharela em Filosofia, Licenciada em Filosofia na UCB Universidade Católica de Brasília - Especialista em Segurança Pública, Especialista em Docência no Ensino Superior, concluindo curso de Mediação e Conflito pela EMAP - Escola de Magistratura do Paraná.

\section{RESUMO}

O objeto é destacar inicialmente que, o meio ambiente é um assunto gerador de grandes debates e um campo de reflexão relativamente novo, de igual modo, os conceitos relacionados com a Ética Ambiental são também recentes. Por outro lado, em contrapartida, observar que a ética é um campo de estudo cuja origem se perde no tempo, o que possibilita uma melhor compreensão da gênese e da evolução da Ética Ambiental. Através da observação, pode se constatar, que a crise que se vive atualmente é, em essência, uma crise ética, quer dizer, de valores, que está profundamente ligada ao modo como o homem se relaciona com o seu mundo natural. Assim, ética e sustentabilidade caminham juntas, devem ser encaradas de maneira multidimensional, sendo composta de cinco dimensões distintas, quais 


\section{Personalidade Acadêmica Homenageada:}

Florisbal de Souza Del'Olmo (Professor Convidado - UNICURITIBA)

sejam: social, ética, jurídico-política, econômica e ambiental. Boff afirma que: Vivemos, hoje, a crise do projeto humano: sentimos a falta clamorosa de cuidado em toda parte. Suas ressonâncias negativas se mostram pela má qualidade de vida, pela penalização da maioria empobrecida da humanidade, pela degradação ecológica e pela exploração exacerbada da violência. Que o cuidado aflore em todos os âmbitos, que penetre na atmosfera humana e que prevaleça em todas as relações! O cuidado salvará a vida, fará justiça ao empobrecido e resgatará a Terra como pátria e mátria de todos. ${ }^{1}$ De acordo com este entendimento, Wolkmer e Paulitsch : [...] a Ética Ambiental pode ser considerada como aquela que advém da necessidade de reexaminarmos nossos valores e princípios em razão dos problemas ambientais e à necessidade de compreendermos as razões que definem a relação do homem com a natureza. Não basta um despertar da consciência individual, necessitamos uma redefinição do quadro ético. ${ }^{2} \mathrm{~A}$ metodologia é biográfica e o resultado almejado com esse trabalho é promover uma reflexão mais aprofundada acerca da ética ambiental.

PALAVRA-CHAVE: Ética Ambiental; Sustentabilidade; Problemas Ambientais; Natureza.

\section{REFERÊNCIAS}

ACSELRAD, Henri. Conflitos ambientais - a atualidade do objeto. In: . Conflitos ambientais no Brasil. Rio de Janeiro: RelumeDumará, 2004

BOFF, Leonardo. Caderno de Debate Agenda 21: Ética e Sustentabilidade. Brasília: Ministério de Meio Ambiente, 2006, p. 191.

\footnotetext{
${ }^{1}$ BOFF, Leonardo. Caderno de Debate Agenda 21: Ética e Sustentabilidade. Brasília: Ministério de Meio Ambiente, 2006, p. 191.

${ }^{2}$ WOLKMER, Maria F. S.; PAULITSCH, Nicole S. Ética Ambiental E Crise Ecológica: reflexões necessárias em busca da sustentabilidade. In: Veredas do Direito, Belo Horizonte, v.8, n.16, p.211233, Julho/Dezembro de 2011.
} 


\section{Personalidade Acadêmica Homenageada:}

Florisbal de Souza Del'Olmo (Professor Convidado - UNICURITIBA)

WOLKMER, Maria F. S.; PAULITSCH, Nicole S. Ética Ambiental E Crise Ecológica: reflexões necessárias em busca da sustentabilidade. In: Veredas do Direito, Belo Horizonte, v.8, n.16, p.211-233, Julho/Dezembro de 2011. 